\title{
Growth and Yield of Hybrid Maize as Influence by Levels of Nitrogen and Biofertilizer
}

\author{
Zothanmawii, Edwin Luikham* and P.S. Mariam Anal \\ College of Agriculture, Central Agriculture University, Iroisemba, \\ Imphal 795004, Manipur, India \\ *Corresponding author
}

Keywords

Nitrogen, Azotobacter, Azospirillum, Growth, Yield, Hybrid maize

Article Info

Accepted:

12 July 2018

Available Online:

10 August 2018

\section{A B S T R A C T}

A field experiment entitled "Influence of bio-fertilizer and nitrogen on growth and yield of hybrid maize (Zea mays L.)" was conducted in 2012 at the Agronomy Experimental Farm of the College of Agriculture, Central Agricultural University, Imphal. The experiment consisting of four nitrogen levels $(0,60,120$ and $180 \mathrm{~kg} \mathrm{~N} / \mathrm{ha})$ and three source of biofertilizers (control, Azotobacter and Azospirillum) was laid out in factorial randomized block design with three replication. The required quantity of nitrogen $(60,120$ and 180 $\mathrm{kg} / \mathrm{ha})$, phosphorus $(60 \mathrm{~kg} / \mathrm{ha}$ ) and potash $(40 \mathrm{~kg} / \mathrm{ha})$ were applied for each plot using Urea, SSP and MOP. Application of different levels of nitrogen and sources of biofertilizers exhibited significant differences in growth characters, yield contributing characters and yield. Application of nitrogen up to $120 \mathrm{~kg} / \mathrm{ha}$ showed significant increase in yield contributing characters as well as the grain yield with an exception in test weight. Among the bio-fertilizers, Azotobacter resulted in significantly higher growth characters, yield contributing characters and yield than Azospirillum and control. The interaction effect between nitrogen and bio-fertilizer was found to be significant in all the characters considered. The treatment combination of $180 \mathrm{~kg} \mathrm{~N} / \mathrm{ha}+$ Azotobacter or Azospirillum inoculation recorded higher grain and stover yield which remained at par to $120 \mathrm{~kg} \mathrm{~N} / \mathrm{ha}+$ Azotobacter. Based on the results obtained from the experiment, it can be concluded that application of $120 \mathrm{~kg} \mathrm{~N} / \mathrm{ha}$ and Azotobacter can be recommended for hybrid maize to get high yield.

\section{Introduction}

Maize (Zea mays L.) is one of the most important cereal crops in the world's agricultural economy both as food for man and feed for animals. It has very high yield potential, there is no cereal on the earth which has so immense potentiality and that is why it is called 'queen of cereals'. Maize crop is utilised in many ways and over 85 per cent of maize produced in the country is consumed as human food. It is also a good feed for poultry, piggery and other animals. It ranks below wheat and sorghum but considerably above rice in nutrition.

Introduction of high yielding varieties/hybrids of maize and adoption of improved production 
technologies enhanced the productivity of maize that resulted in more turn-over of the nutrients from the soil. With almost twice the quantity of plant nutrients being removed from the soil than what is added through fertilizers, the growing plant nutrient imbalance poses a major threat to sustain soil health and crop productivity in India. The need for continued increase in food and fodder production to meet the ever expanding human and livestock population and inadequate domestic fertilizer supplies coupled with the inability of chemical fertilizers to maintain long-term soil health and crop productivity in intensive cropping systems have underlined the need for integrated nutrient supply system. This involves the combined use of different nutrient sources such as chemical fertilizers, organic manures, bio-fertilizers, etc.

Maize is an exhaustive crop and therefore, needs adequate supply of nutrients particularly nitrogen for better growth and yield. Nitrogen is an integral part of chlorophyll, which is the primary absorber of light energy needed for photosynthesis and also imparts vigorous vegetative growth, dark green colour to plants. Inside the plant, Nitrogen converts to amino acids, the building blocks for proteins. These amino acids are then used in forming protoplasm, which is used in cell division. These amino acids are also utilized in producing necessary enzymes and structural parts of the plant and can become part of the stored proteins in the grain. In the first 25 days of a corn plants growth, it will absorb 8 per cent of its total nitrogen. This is critical because the corn plant determines the number of kernel rows in the first 25 days of growth. The number of kernel rows can dramatically influence yield, so placement in the root zone is extremely important. Nitrogen deficiency shows up in the yellowing or chlorosis of the plant leaves. Plants will typically be shorter or stunted and grow slower than plants with sufficient nitrogen. Nitrogen stress also reduces the amount of protein in the seed and plant.

Nitrogenous fertilizer, synthesized from fossil fuel, is a major limiting factor in agricultural productivity due to its depleting reserves. Therefore, an alternate source of nitrogen will have to be found out for crop plants. Biofertilizers have emerged as an important component of the integrated nutrient supply systems and hold a great promise to improve crop yields through environmentally better nutrient supplies. Azotobacter a free-living soil microbes will play an important role in the nitrogen cycle in nature, binding atmospheric nitrogen, which is inaccessible to plants, and releasing it in the form of ammonium ions into the soil. The aerobic bacteria Azotobacter chroococcum known to fix considerable quantity of nitrogen in the range of $20-40 \mathrm{~kg}$ of nitrogen per hectare in the rhizosphere in non-leguminous crops. The bacterium produces growth-promoting substances like Indole acetic acid, gibberellins, pantothenic acid, thiamine and niacin which promotes root proliferation and improve the plant growth and yield. It increases the rootlet density and root branching resulting in the increased uptake of mineral and water.

Effectiveness of inoculation on plant growth enhancement and crop yields depends upon its ability to survive and multiply in soils and is influenced by many abiotic and biotic factors including texture, $\mathrm{pH}$, temperature, moisture content, soil type, soil amendment, nutritional status of the plant, plant species, plant age, microbial competition and predation.

The high cost of nitrogen fertilizers is often prohibitive to the small and marginal farmers. It is therefore important to explore alternative sources of nitrogen to partly meet the nitrogen requirement. Thus, the use of bio-fertilizers would be more remunerative and cost effective for getting higher returns with 
considerable fertilizer economy and better soil health.

\section{Materials and Methods}

The experiment was conducted during the prekharif season of 2012 at the Agronomy Research Farm of the College of Agriculture, Central Agricultural University, Imphal. The experimental site is situated at $24^{\circ} 45^{\prime} \mathrm{N}$ latitude and $93^{\circ} 56^{\prime}$ E longitude and at an altitude of $790 \mathrm{~m}$ above sea level. The mean minimum and maximum temperature recorded during the cropping season were 14.6 and 29.5 ${ }^{\circ} \mathrm{C}$, respectively. The total rainfall recorded was $18 \mathrm{~mm}$. The average relative humidity in the morning hours was $79.9 \%$ and in the evening $56 \%$.

The average sunshine hour was 6.3 and wind speed recorded $5 \mathrm{~km} / \mathrm{hr}$. The soil of the experimental site was clay in texture with a $\mathrm{pH}$ of 5.9 and available nitrogen $301.0 \mathrm{~kg}$ $\mathrm{N} /$ ha (medium), phosphorus $13.8 \mathrm{~kg} \mathrm{P}_{2} \mathrm{O}_{5} / \mathrm{ha}$ (medium) and potash $355.4 \mathrm{~kg} \mathrm{~K}_{2} \mathrm{O} / \mathrm{ha}$ (high). Hybrid maize variety Varsha was chosen for this study. The prime objective of the experiment was to study the influence of biofertilizer and nitrogen on growth parameters and yield of hybrid maize.

The field experiment was laid out in Factorial randomized block design with three replications. The treatment consists of four nitrogen levels $(0,60,120$ and $180 \mathrm{~kg} \mathrm{~N} / \mathrm{ha})$ and three sources of bio-fertilizers (control, Azotobacter and Azospirillum). A uniform dose of $60 \mathrm{~kg}$ phosphorus (through SSP, 16\% $\mathrm{P}_{2} \mathrm{O}_{5}$ ) and $40 \mathrm{~kg}$ potash (through MOP, $60 \%$ $\mathrm{K}_{2} \mathrm{O}$ ) per hectare and required amount of nitrogen as per treatment was applied in furrows, made $60 \mathrm{~cm}$ apart one day before sowing at $4-5 \mathrm{~cm}$ depth. Half of the total nitrogen, full dose of $\mathrm{P}_{2} \mathrm{O}_{5}$ and $\mathrm{K}_{2} \mathrm{O}$ were applied as basal dose just a day before sowing of seeds and well mixed with the soil. The remaining half dose of nitrogen was applied in two equal splits at knee high stage and tasseling stage. Seeds were inoculated with Azotobacter and Azospirillum (20 g/kg seed) just before sowing as per the treatment. A slurry of inoculant and jaggery solution was prepared and crop seed mixed with it to have uniform coating over the seeds, which were dried for 30 minutes under shade, then seeds were sown immediately. All other agronomic practices were followed as per the standard. The hybrid variety of maize 'Varsha' was sown on $23^{\text {rd }}$ February 2012 and harvested on $30^{\text {th }}$ June 2012.

The observations on growth parameters viz., plant height, fresh and dry weight of plant and leaf area index were measured at 30, 60, 90 and 120 days after sowing. The yield parameters number of cobs per plant, cob length, cob girth, number of grain per cob and test weight was recorded.

\section{Results and Discussion}

\section{Plant height (cm)}

Plant height is reliable index of growth and developments representing the infrastructure build up by the plant over a period of time. The data recorded at various growth stages revealed that there was significant increase in plant height due to application of nitrogen (Table 1). In all the stages of recording with an exception at 60 DAS the plant height increased consistently and significantly up to $120 \mathrm{~kg} \mathrm{~N} / \mathrm{ha}$. However, at 60 DAS the plant height increased significantly up to $180 \mathrm{~kg}$ $\mathrm{N} / \mathrm{ha}$. Adequate nitrogen application increases the cell division, cell elongation, nucleus formation as well as green foliage. It also encourages the shoot growth. Therefore, higher doses of nitrogen increased the chlorophyll content which increased the rate of photosynthesis and extension of stem resulting increased plant height (Diallo et al., 
1996 and Thakur et al., 1998). Shivay and Singh (2000) also observed that application of nitrogen increased plant height by increasing length and number of internodes.

Inoculations of Azotobacter showed significantly taller plant over that of Azospirillum and control at all the growth stages. This might be due to the growth promoting effect showed by the beneficial microbe. This finding is also supported by $\mathrm{Wu}$ et al., (2005).

\section{Fresh weight and dry weight (g/plant)}

The fresh and dry weights of plant were significantly influenced at various stages by the application of nitrogen. Though maximum fresh and dry weight was observed with 180 $\mathrm{kg} \mathrm{N} / \mathrm{ha}$, however, the increase was significant up to $120 \mathrm{~kg} \mathrm{~N} / \mathrm{ha}$ (Table 2 and 3). Beneficial effect of nitrogen application on fresh and dry weight of plant was also reported by Kumar (2008) and Siam et al., 2008. Raju et al., (1997) also reported that higher doses of nitrogen applied to maize increased its availability and uptake, resulting in production of more photosynthates in terms of dry matter.

Remarkably fresh weight and dry weight of plant was recorded with the inoculation of Azotobacter. Azotobacter can affect plant growth not only by fixing nitrogen but also by altering microbial balance, suppression of pathogenic microorganisms, metabolism of soil phosphate and by providing metabolites that stimulate plant development after germination (Meshram and Shende, 1982). The effect on dry weight of plant with Azotobacter inoculation are in line with the earlier report of Jarak et al., (2012) in maize.

\section{Leaf area index (LAI)}

LAI is an important plant growth index which determines the capacity of plants to trap solar energy for photosynthesis. The LAI increased progressively with the increase in age and reached maximum at 90 DAS and declined thereafter till harvest (Table 4). The maximum value of LAI was recorded with application of $180 \mathrm{~kg} \mathrm{~N} / \mathrm{ha}$ at 30 and 60 DAS. However, at later stages it remained at par to $120 \mathrm{~kg} \mathrm{~N} / \mathrm{ha}$. This might be due to increase in leaf number and size, photosynthetic pigment in leaves with proper supply of nitrogen at higher dose resulting in more and larger photosynthetic apparatus of the crop which consequently influence the assimilated product. The beneficial effect of nitrogen on LAI was in conformity with the earlier findings of Sharar et al., (2003), Bindhani et al., (2007) and Meena et al., (2007). Similarly, Oscar and Tollenaar (2006) concluded that LAI of maize increased with the application of higher rate of nitrogen and decline in lower doses.

Irrespective of the growth stages, inoculation of Azotobacter remarkably enhanced the LAI as compared to Azospirillum and control. Maximum LAI was observed at 90 DAS and decline thereafter, this might be due to increase in aging of leaves.

\section{Yield contributing characters and yield}

\section{Number of cobs per plant}

The number of cobs per plant increased significantly with every increase in the level of nitrogen up to $120 \mathrm{~kg} \mathrm{~N} /$ ha (Table 5). Higher LAI recorded in this level of nitrogen might have helped the crop to capture more solar radiation thereby leading to increased number of cobs per plant. Bangarwa et al., (1988) and Kumar, 2008 also reported that adequate supply of nitrogen resulted in easy and greater availability of nitrogen to the crop which consequently increase the number of cobs. A significant increase in number of cobs per plant as a consequence of seed inoculation with Azotobacter in the present investigation is attributed to an improvement in nutrition 
status of the soil and creation of congenial environment for better root growth through secretion of growth promoting substances such as Gibberellin, cytokinin and auxin and availability of nitrogen fixed by the microorganisms (Singh and Totawat, 2002).

\section{Cob length $(\mathrm{cm})$}

The maximum length of cob was recorded with application of $120 \mathrm{~kg} \mathrm{~N} / \mathrm{ha}$. This might be due to better nitrogen uptake and increased translocation of photosynthates from source to sink with adequate supply of nitrogen. The findings are in agreement with those of Sahoo and Mahapatra (2004) and Ananthi et al., (2011).

The highest cob length was observed with Azotobacter inoculation which was superior to Azospirillum and control. The possible reason could be better absorption of essential nutrients, synthesize phytohormones that promote the ear length. Similar positive effect of Azotobacter was also reported by Biari et $a l$. , (2008) on cob length of maize.

\section{Cob girth (cm)}

The cob girth increases with each increment in nitrogen up to $120 \mathrm{~kg} \mathrm{~N} / \mathrm{ha}$. Increase in cob girth of maize and baby corn with increasing levels of nitrogen was observed by Selvaraju and Iruthayaraj (1994) and Bindhani et al., (2007). Inoculation of seed with Azotobacter was significantly superior to Azospirillum and control in respect of cob girth. The increase in cob girth with the inoculation of Azotobacter in maize was reported by Abbass and Okon (1993).

\section{Number of grains per cob}

Significant increase in number of grains per cob was recorded with increasing dose of nitrogen up to $120 \mathrm{~kg} \mathrm{~N} / \mathrm{ha}$. The lesser number of grains in lower dose of nitrogen might be due to nitrogen deficiency which reduced biomass production traits of the plant and ultimately reflecting to number of grains per cob. The results are in agreement with the earlier findings of Hammad et al., (2011) and Dawadi and Sah (2012)

Azospirillum and control resulted in lesser number of grains/cob as compared to Azotobacter. The increase in grains per cob with Azotobacter inoculation has been reported by Sharifi et al., (2011) in maize.

\section{Test weight (g)}

The test weight increases with each increment in nitrogen levels up to $120 \mathrm{~kg} \mathrm{~N} / \mathrm{ha}$. Such positive role of nitrogen in enhancing the test weight of maize is also recorded by Arif et al., (2010) and Salam et al., (2010).

Inoculation of Azotobacter showed higher value of test weight over control but remained at par to Azospirillum. The findings are in agreement with those of Biari et al., (2008) in maize.

\section{Grain yield (q/ha)}

The grain yield was significantly affected by nitrogen application. Application of $120 \mathrm{~kg}$ $\mathrm{N} /$ ha showed a significant superiority over that of control and $60 \mathrm{~kg} \mathrm{~N} / \mathrm{ha}$ and was at par with $180 \mathrm{~kg} \mathrm{~N} / \mathrm{ha}$ in respect of grain yield (Table $5)$.

Such a positive yield response of nitrogen application is obvious when it is deficient in the growing medium. The soil sample analysed before the start of the experiment also showed that the available nitrogen status of soil in the experimental site was in medium range $(301.0 \mathrm{~kg} \mathrm{~N} / \mathrm{ha})$. Application of nitrogen, therefore, provided better nutrition to maize which resulted in higher grain yield. 
Table.1 Effect of nitrogen and biofertilizer on plant height $(\mathrm{cm})$

\begin{tabular}{|c|c|c|c|c|c|c|c|c|c|c|c|c|c|c|c|c|}
\hline \multirow[t]{2}{*}{ Treatment } & \multicolumn{4}{|c|}{30 DAS } & \multicolumn{4}{|c|}{60 DAS } & \multicolumn{4}{|c|}{90 DAS } & \multicolumn{4}{|c|}{120 DAS } \\
\hline & $\mathrm{B}_{0}$ & $\mathrm{~B}_{1}$ & $\mathrm{~B}_{2}$ & Mean & $\mathrm{B}_{0}$ & $\mathrm{~B}_{1}$ & $\mathrm{~B}_{2}$ & Mean & $\mathrm{B}_{0}$ & $\mathrm{~B}_{1}$ & $\mathrm{~B}_{2}$ & Mean & $\mathrm{B}_{0}$ & $\mathrm{~B}_{1}$ & $\mathrm{~B}_{2}$ & Mean \\
\hline $\mathbf{N}_{0}$ & 21.73 & 25.37 & 23.57 & 23.56 & 81.33 & 103.20 & 91.70 & 92.08 & 124.50 & 158.30 & 143.80 & 142.20 & 161.40 & 195.07 & 175.80 & 177.42 \\
\hline $\mathbf{N}_{1}$ & 24.03 & 27.53 & 25.80 & 25.79 & 99.07 & 114.13 & 107.40 & 106.87 & 156.10 & 185.17 & 166.77 & 169.34 & 179.27 & 210.90 & 194.07 & 194.74 \\
\hline $\mathbf{N}_{2}$ & 25.77 & 30.53 & 28.30 & 28.20 & 109.57 & 128.73 & 117.00 & 118.43 & 184.93 & 218.33 & 192.47 & 198.58 & 199.63 & 225.07 & 211.93 & 212.21 \\
\hline $\mathbf{N}_{3}$ & 27.80 & 32.47 & 30.17 & 30.14 & 119.70 & 141.13 & 131.53 & 130.79 & 194.73 & 229.83 & 213.90 & 212.82 & 210.20 & 236.83 & 229.53 & 225.52 \\
\hline Mean & 24.83 & 28.98 & 26.96 & & 102.42 & 121.80 & 111.91 & & 165.06 & 197.91 & 179.23 & & 187.63 & 216.97 & 202.83 & \\
\hline & $\mathrm{N}$ & B & $\begin{array}{ll}N & x \\
B & \end{array}$ & & $\mathrm{~N}$ & B & $\mathrm{N} \times \mathrm{B}$ & & $\mathrm{N}$ & B & $\mathrm{N} \times \mathrm{B}$ & & $\mathrm{N}$ & B & $\mathrm{N} \times \mathrm{B}$ & \\
\hline SEd+- & 1.02 & 0.89 & 1.77 & & 4.60 & 3.98 & 7.96 & & 7.59 & 6.58 & 13.15 & & 7.38 & 6.39 & 12.78 & \\
\hline $\mathrm{CD}(\mathrm{P}=0.05)$ & 2.12 & 1.84 & 3.67 & & 9.54 & 8.25 & 16.51 & & 15.74 & 13.65 & 27.27 & & 15.31 & 13.25 & 26.51 & \\
\hline
\end{tabular}

Table.2 Effect of nitrogen and biofertilizer on fresh weight of plant (g/plant)

\begin{tabular}{|c|c|c|c|c|c|c|c|c|c|c|c|c|c|c|c|c|}
\hline Treatment & \multicolumn{4}{|c|}{30 DAS } & \multicolumn{4}{|c|}{60 DAS } & \multicolumn{4}{|c|}{90 DAS } & \multicolumn{4}{|c|}{120 DAS } \\
\hline & $\mathrm{B}_{0}$ & $\mathrm{~B}_{1}$ & $\mathrm{~B}_{2}$ & Mean & $\mathrm{B}_{0}$ & $\mathrm{~B}_{1}$ & $\mathrm{~B}_{2}$ & Mean & $\mathrm{B}_{0}$ & $\mathrm{~B}_{1}$ & $\mathrm{~B}_{2}$ & Mean & $\mathrm{B}_{0}$ & $\mathrm{~B}_{1}$ & $\mathrm{~B}_{2}$ & Mean \\
\hline $\mathbf{N}_{0}$ & 2.33 & 2.65 & 2.55 & 2.51 & 46.00 & 61.03 & 55.67 & 54.23 & 130.00 & 153.27 & 151.67 & 144.98 & 156.13 & 205.00 & 178.07 & 179.73 \\
\hline $\mathbf{N}_{1}$ & 2.59 & 2.94 & 2.73 & 2.75 & 78.33 & 89.33 & 81.77 & 83.14 & 154.47 & 188.10 & 160.00 & 167.52 & 186.23 & 221.67 & 208.33 & 205.41 \\
\hline $\mathbf{N}_{2}$ & 2.90 & 3.48 & 3.17 & 3.18 & 92.20 & 117.00 & 103.80 & 104.33 & 163.37 & 210.00 & 184.63 & 186.00 & 210.00 & 256.47 & 224.93 & 230.47 \\
\hline $\mathbf{N}_{3}$ & 3.23 & 3.67 & 3.50 & 3.47 & 108.33 & 133.03 & 120.33 & 120.57 & 186.60 & 218.33 & 205.00 & 203.31 & 228.87 & 273.33 & 256.67 & 252.96 \\
\hline Mean & 2.76 & 3.19 & 2.99 & & 81.22 & 100.10 & 90.39 & & 158.61 & 192.43 & 175.33 & & 195.31 & 239.12 & 217.00 & \\
\hline & $\mathrm{N}$ & B & $\begin{array}{ll}N & x \\
B & \end{array}$ & & $\mathrm{~N}$ & B & $\mathrm{N} \times \mathrm{B}$ & & $\mathrm{N}$ & B & $\mathrm{N} \times \mathrm{B}$ & & $\mathrm{N}$ & B & $\mathrm{N} \times \mathrm{B}$ & \\
\hline SEd+- & 0.10 & 0.09 & 0.18 & & 4.58 & 3.97 & 7.93 & & 8.61 & 7.45 & 14.91 & & 11.60 & 10.05 & 20.10 & \\
\hline $\begin{array}{l}\text { CD } \\
(P=0.05)\end{array}$ & 0.21 & 0.19 & 0.38 & & 9.50 & 8.23 & 16.45 & & 17.85 & 15.46 & 30.92 & & 24.06 & 20.84 & 41.69 & \\
\hline
\end{tabular}


Table.3 Effect of nitrogen and biofertilizer on dry weight of plant (g/plant)

\begin{tabular}{|c|c|c|c|c|c|c|c|c|c|c|c|c|c|c|c|c|}
\hline \multirow[t]{2}{*}{ Treatment } & \multicolumn{4}{|c|}{$30 \mathrm{DAS}$} & \multicolumn{4}{|c|}{$60 \mathrm{DAS}$} & \multicolumn{4}{|c|}{90 DAS } & \multicolumn{4}{|c|}{120 DAS } \\
\hline & $\mathrm{B}_{0}$ & $\mathrm{~B}_{1}$ & $\mathrm{~B}_{2}$ & Mean & $\mathrm{B}_{0}$ & $\mathrm{~B}_{1}$ & $\mathrm{~B}_{2}$ & Mean & $\mathrm{B}_{0}$ & $\mathrm{~B}_{1}$ & $\mathrm{~B}_{2}$ & Mean & $\mathrm{B}_{0}$ & $\mathrm{~B}_{1}$ & $\mathrm{~B}_{2}$ & Mean \\
\hline $\mathbf{N}_{\mathbf{0}}$ & 0.450 & 0.497 & 0.453 & 0.467 & 8.69 & 13.02 & 11.63 & 11.11 & 45.43 & 51.63 & 46.70 & 47.92 & 53.30 & 66.67 & 58.33 & 59.43 \\
\hline $\mathbf{N}_{1}$ & 0.473 & 0.653 & 0.610 & 0.579 & 11.63 & 17.34 & 15.57 & 14.89 & 56.50 & 65.17 & 58.33 & 60.00 & 64.87 & 80.07 & 72.70 & 72.54 \\
\hline $\mathbf{N}_{2}$ & 0.593 & 0.777 & 0.643 & 0.671 & 14.54 & 19.67 & 16.97 & 17.06 & 60.10 & 76.67 & 69.77 & 68.84 & 73.33 & 95.03 & 89.93 & 86.10 \\
\hline $\mathbf{N}_{3}$ & 0.700 & 0.829 & 0.753 & 0.761 & 17.20 & 21.33 & 19.12 & 19.22 & 63.37 & 83.30 & 77.27 & 74.64 & 80.70 & 111.67 & 95.00 & 95.79 \\
\hline Mean & 0.554 & 0.689 & 0.615 & & 13.05 & 17.84 & 15.82 & & 56.35 & 69.19 & 63.02 & & 68.05 & 88.36 & 78.99 & \\
\hline & $\mathrm{N}$ & B & $\mathrm{N} \times \mathrm{B}$ & & $\mathrm{N}$ & B & $\begin{array}{ll}N & X \\
B & \end{array}$ & & $\mathrm{~N}$ & B & $\mathrm{N} \times \mathrm{B}$ & & $\mathrm{N}$ & B & $\mathrm{N} \times \mathrm{B}$ & \\
\hline SEd+- & 0.034 & 0.029 & 0.058 & & 0.90 & 0.78 & 1.55 & & 3.36 & 2.91 & 5.82 & & 4.69 & 4.06 & 8.13 & \\
\hline $\begin{array}{l}\text { CD } \\
(P=0.05)\end{array}$ & 0.071 & 0.060 & 0.120 & & 1.87 & 1.61 & 3.21 & & 6.97 & 6.04 & 12.07 & & 9.73 & 8.42 & 16.86 & \\
\hline
\end{tabular}

Table.4 Effect of nitrogen and biofertilizer on LAI

\begin{tabular}{|c|c|c|c|c|c|c|c|c|c|c|c|c|c|c|c|c|}
\hline \multirow[t]{2}{*}{ Treatment } & \multicolumn{4}{|c|}{30 DAS } & \multicolumn{4}{|c|}{60 DAS } & \multicolumn{4}{|c|}{90 DAS } & \multicolumn{4}{|c|}{120 DAS } \\
\hline & $\mathrm{B}_{0}$ & $\mathrm{~B}_{1}$ & $\mathrm{~B}_{2}$ & Mean & $\mathrm{B}_{0}$ & $\mathrm{~B}_{1}$ & $\mathrm{~B}_{2}$ & Mean & $\mathrm{B}_{0}$ & $\mathrm{~B}_{1}$ & $\mathrm{~B}_{2}$ & Mean & $\mathrm{B}_{0}$ & $\mathrm{~B}_{1}$ & $\mathrm{~B}_{2}$ & Mean \\
\hline $\mathbf{N}_{0}$ & 0.207 & 0.357 & 0.280 & 0.281 & 1.100 & 1.333 & 1.267 & 1.233 & 1.57 & 1.90 & 1.70 & 1.72 & 0.500 & 0.700 & 0.567 & 0.589 \\
\hline $\mathbf{N}_{1}$ & 0.327 & 0.453 & 0.360 & 0.380 & 1.367 & 1.600 & 1.500 & 1.489 & 1.80 & 2.23 & 2.03 & 2.02 & 0.633 & 0.833 & 0.733 & 0.733 \\
\hline $\mathbf{N}_{2}$ & 0.483 & 0.570 & 0.533 & 0.529 & 1.700 & 2.267 & 1.900 & 1.956 & 2.07 & 2.70 & 2.33 & 2.37 & 0.800 & 1.133 & 0.867 & $\mathbf{0 . 9 3 3}$ \\
\hline $\mathbf{N}_{3}$ & 0.510 & 0.650 & 0.619 & 0.593 & 1.933 & 2.433 & 2.233 & 2.200 & 2.37 & 2.83 & 2.60 & 2.60 & 0.900 & 1.167 & 1.067 & 1.044 \\
\hline Mean & 0.382 & 0.508 & 0.448 & & 1.525 & 1.908 & 1.725 & & 1.95 & 2.42 & 2.17 & & 0.708 & 0.958 & 0.808 & \\
\hline & $\mathrm{N}$ & B & $\mathrm{N} \times \mathrm{B}$ & & $\mathrm{N}$ & B & $\begin{array}{ll}N & x \\
B & \end{array}$ & & $\mathrm{~N}$ & B & $\mathrm{N} \times \mathrm{B}$ & & $\mathrm{N}$ & B & $\mathrm{N} \times \mathrm{B}$ & \\
\hline SEd+- & 0.031 & $\mathbf{0 . 0 2 7}$ & 0.053 & & 0.084 & 0.073 & 0.146 & & 0.11 & 0.10 & 0.20 & & 0.053 & 0.046 & 0.093 & \\
\hline $\mathrm{CD}(\mathrm{P}=0.05)$ & 0.064 & 0.056 & 0.110 & & 0.174 & 0.151 & 0.303 & & 0.23 & 0.21 & 0.41 & & 0.110 & 0.095 & 0.193 & \\
\hline
\end{tabular}


Table.5 Effect of nitrogen and biofertilizer on yield attributing characters, grain and stover yield

\begin{tabular}{|c|c|c|c|c|c|c|c|}
\hline Treatment & $\begin{array}{l}\text { No. of } \\
\text { cobs/plant }\end{array}$ & $\begin{array}{l}\text { Cob } \\
\text { length }(\mathrm{cm})\end{array}$ & $\begin{array}{l}\text { Cob } \\
\text { girth(cm) }\end{array}$ & $\begin{array}{l}\text { No. of } \\
\text { grains/cob }\end{array}$ & $\begin{array}{l}\text { Test } \\
\text { weight(g) }\end{array}$ & $\begin{array}{l}\text { Grain } \\
\text { yield(q/ha) }\end{array}$ & $\begin{array}{l}\text { Stover } \\
\text { yield(q/ha) }\end{array}$ \\
\hline \multicolumn{8}{|c|}{ Levels of Nitrogen } \\
\hline $\mathbf{N}_{\mathbf{0}}$ & 1.489 & 14.20 & 14.30 & 434.11 & 330.30 & 40.50 & 62.37 \\
\hline $\mathbf{N}_{1}$ & 1.733 & 16.18 & 16.14 & 483.44 & 337.76 & 47.45 & 75.11 \\
\hline $\mathbf{N}_{2}$ & 2.122 & 18.17 & 16.84 & 517.44 & 351.31 & 57.97 & 102.13 \\
\hline $\mathbf{N}_{3}$ & 2.244 & 19.33 & 17.29 & 530.56 & 356.70 & 60.19 & 111.53 \\
\hline SEd+- & 0.069 & 0.56 & 0.26 & 8.43 & 4.76 & 1.58 & 5.78 \\
\hline $\mathrm{CD}(\mathrm{p}=0.05)$ & 0.143 & 1.16 & 0.54 & 17.48 & 9.87 & 3.28 & 11.99 \\
\hline \multicolumn{8}{|c|}{ Source of biofertilizer } \\
\hline $\mathbf{B}_{0}$ & 1.750 & 15.51 & 15.27 & 473.83 & 334.70 & 47.13 & 78.76 \\
\hline $\mathbf{B}_{1}$ & 2.042 & 18.41 & 16.83 & 508.75 & 352.80 & 55.51 & 96.79 \\
\hline $\mathbf{B}_{2}$ & 1.900 & 16.99 & 16.33 & 491.58 & 344.55 & 51.96 & 87.79 \\
\hline SEd+- & 0.060 & 0.49 & 0.22 & 7.30 & 4.12 & 1.37 & 5.00 \\
\hline $\mathrm{CD}(\mathrm{p}=0.05)$ & 0.124 & 1.02 & 0.46 & 15.14 & 8.54 & 2.84 & 10.37 \\
\hline SEd+-(NxB) & 0.120 & 0.98 & 0.45 & 14.60 & 8.25 & 2.74 & 10.00 \\
\hline $\begin{array}{l}\mathrm{CD} \text { for } \mathrm{NxB} \\
(\mathrm{p}=0.005)\end{array}$ & 0.249 & 2.03 & 0.93 & 30.28 & 17.11 & 5.68 & 20.74 \\
\hline
\end{tabular}

Increase in grain yield with the application of nitrogen may be attributed to better growth of plant as expressed in terms of plant height, fresh weight and dry weight of plant and LAI which were favourably affected by nitrogen fertilization. The improvement in growth resulted in significant increase in yield attributes like number of cobs per plant, grains per cob, cob length and cob girth and test weight which ultimately contributed to higher grain yield with the application of nitrogen. The beneficial effect of nitrogen on grain yield of maize has also been reported by Sahoo and Mahapatra (2004), Kumar (2008) and Srikanth et al., (2009). The grain yield of maize was significantly higher with Azotobacter seed inoculation compared to Azospirillum and control. Again Azospirillum recorded higher grain yield over that of control. The reported increase in grain yield due to bio-fertilizer may be on account of its direct role in nitrogen fixation and also due to production of phytohormones like Indole acetic acid, Gibberellins and Cytokinin. Thus, adequate and continuous supply of nitrogen to the crop resulted in better growth and consequently higher yield. The higher grain yield associated with Azotobacter may also be attributed to more number of cobs per plant, cob length and girth and grains per cob. This finding is also supported by Mala et al., (2010) and Farboodi et al., (2011).

\section{Stover yield (q/ha)}

Stover yield increased significantly with the application of nitrogen up to $120 \mathrm{~kg} \mathrm{~N} / \mathrm{ha}$. The higher stover yield associated with the application of nitrogen can be attributed to better growth of the plant as expressed in terms of plant height, fresh and dry weight of the plant and LAI. This finding confirms the earlier report of Meena et al., (2007) and Siam et al., (2008).. The results of the present investigation have clearly indicated that application of biofertilizer had remarkably increased the stover yield. Between the bio-fertilizer significantly higher stover yield was recorded with the inoculation of Azotobacter as compared to Azospirillum. Higher stover yield with the 
inoculation of Azotobacter have also been reported by Patil et al., (1992).

\section{Interaction}

The Interaction effect of $180 \mathrm{~kg} \mathrm{~N} / \mathrm{ha}+$ Azotobacter showed similar trend with $180 \mathrm{~kg}$ $\mathrm{N} / \mathrm{ha}+$ Azospirillum and $120 \mathrm{~kg}$ N/ha + Azotobacter in all the characters studied with few exception. Maize growth and yield were markedly increased when bio-fertilizers were combined with nitrogenous fertilizer. This finding was supported by Patil et al., (1992) and Rout et al., (2001).

\section{References}

Abbass, Z. and Y. Okon. 1993. Plant growth promotion by Azotobacter paspali in the rhizosphere. Soil Biol. Biochem. 25:1075-1083.

Ananthi, T., M.M. Amanullah and K.S. Subramanian. 2011. Influence of fertilizer levels and mycoorrhiza on yield attributes, yield and grain quality of hybrid maize. Madras Agric. J. 98(10-12): 362-366.

Arif, M., M.T. Jan, N.U. Khan, H. Akbar, S.A. Khan, M.J. Khan, A. Khan, I. Munir, M. Saeed and A. Iqbal. 2010. Impact of plant populations and nitrogen levels on maize. Pak. J. Bot. 42(6): 3907-3913.

Bangarwa, A.S., M.S. Kairon and K.P. Singh. 1988. Effect of plant density, and level and proportion of nitrogen fertilization on growth, yield and components of winter maize (Zea mays). Indian. J. Agric. Sci. 58(11): 854-856.

Biari, A., A. Gholami and H..A. Rahmani. 2008. Growth promotion and enhanced nutrient uptake of maize (Zea mays L.) by application of plant growth promoting rhizobacteria in arid region of Iran. J. Biol. Sci. 8(6): 1015-1020.

Bindhani, A., K.C. Barik, L.M. Garnayak and P.K. Mahapatra. 2007. Nitrogen management in baby corn (Zea mays). Indian J. Agron. 52(2): 135-138.

Dawadi, D.R. and S.K. Sah. 2012. Growth and yield of hybrid maize (Zea mays L.) in relation to planting density and nitrogen levels during winter season in Nepal. Trop. Agric. Res. 23(3): 218-227.

Diallo, A.O., A.Adam, R.K. Akanvou and P.Y.K. Sallah.1996. Response of maize lines evaluated under stress and nonstress environment. In: Edmeades GO, Banziger M, Mickelson HR and PenaValdivia CB (eds.) Developing Drought and Low N Tolerance Maize. Proceedings of a symposium, PP 28086, March 25-29, 1996, CIMMYT, EI Batan, Mexico.

Farboodi, M., M. Alizadeh, A. Faramarzi, S. Shahrokhi and A. Fallah. 2011. Azotobacter inoculation, nitrogen fertilizer and manure level effects on morphological characteristics of corn SC-647, in a greenhouse study. Int. Conf. on Biol., Environ. and Chem. IPCBEE vol. 24 PP 485-488, 2011 IACSIT Press, Singapore.

Hammad, H.M., A. Ahmad, A. Wajid and J. Akhter. 2011. Maize response to time and rate of nitrogen application. Pak. J. Bot. 43(4): 1935-1942.

Jarak, M., N. Mrkovacki, D. Bjelic, D. Josic, T.H. Jafari and D. Stamenov. 2012. Effects of plant growth promoting rhizobacteria on maize in greenhouse and field trial. Afr. J. Microb. Res. 6(27): 5683-5690.

Kumar, A. 2008. Productivity, economics and nitrogen-use efficiency of specialty corn (Zea mays) as influenced by planting density and nitrogen fertilization. Indian J. Agron. 53(4): 306-309.

Mala, T., S. Chotchuangmaneerat, W. Phuengsaeng and J. Phumphet. 2010. Efficiency of Glomus aggregatum, Azotobacter, Azospirillum and chemical fertilizer on growth and yield of single cross hybrid 4452 maize. Kasetsart J. (Nat Sci) 44: 789-799.

Meena, O., H.R. Khafi, M.A. Shekh, A.C. Mehta and B.K. Davda. 2007. Effect of vermicompost and nitrogen on content, uptake and yield of rabi maize. Crop 
Res. 33(1, 2 \& 3): 53-54.

Meshram, S.U. and S.T. Shende. 1982. Response of maize to Azotobacter chroococcum. Plant Soil. 69(1-3): 265273.

Oscar, R.V. and M. Tollenaar. 2006. Effect of genotype, nitrogen, plant density and row spacing on the area-per-leaf profile in maize. Agron. J. 98: 94-99.

Patil, S.K., A.A. Pisal and J.S. Desale.1992. Response of fodder maize (Zea mays) to bio-fertilizers. Indian J. Agron. 37(2): 357-358.

Raju, M.S., A. Srinivas and V. Raju. 1997. Performance of promising pre-released maize varieties to different nitrogen levels under rainfed conditions. Ann. Arid Zone. 36(4): 377-379.

Rout, D., M.R. Satapathy and B.K. Mohapatra. 2001. Effect of bio-fertilizers on nitrogen economy in maize. Madras Agric. J. 88(7-9): 530-532.

Sahoo, S.C. and P.K. Mahapatra. 2004. Response of sweet corn (Zea mays) to nitrogen levels and plant population. Indian J. Agric. Sci.74(6): 337-338.

Salam, M.A., M.S.A. Sarder, M.J. Ullah, M.A. Kawochar and M.K. Islam. 2010. Effect of different spacing and levels of nitrogen fertilizer on the yield attributes and yield of hybrid maize. J. Expt. Biosci. 1(2): 57-61.

Selvaraju, R. and M.R. Iruthayaraj.1994. Influence of irrigation scheduling, methods of irrigation and nitrogen levels on growth and yield of maize. Madras. Agric. J. 81(8): 418-420.

Sharar, M.S., M. Ayub, M.A. Nadeem and M. Ahmad. 2003. Effect of different rates of nitrogen and phosphorus on growth and grain yield of maize (Zea mays L.). Asian. J. Pl. Sci. 2(3): 347-349.

Sharifi, R.S., K. Khavazi and A. Gholipouri.
2011. Effect of seed priming with plant growth promoting Rhizobacteria (PGPR) on dry matter accumulation and yield of maize (Zea mays L.) hybrids. Int. Res. J. Biochem. Bioinform. 1(3): 76-83.

Shivay, Y.S and R.P. Singh. 2000. Growth, yield attributes, yields and nitrogen uptake of maize (Zea mays L.) as influenced by cropping systems and nitrogen levels. Ann. Agric. Res., 21(4): 494-498.

Siam, H., M.G. Abd-El-Kader and H.I. ElaAlia. 2008. Yield and yield components of maize as affected by different sources and application rates of nitrogen fertilizer. Res. Agric. \& Biol. Sci. 4(5): 399-412.

Singh, R., and K.L. Totawat. 2002. Effect of integrated use of nitrogen on the performance of maize (Zea mays L.) on haplustalfs of sub-humid southern plains of Rajasthan. Indian J. Agric. Res. 36(2): 102-107.

Srikanth, M., M.M. Amanullah, P. Muthukrishnan and K.S. Subramanian. 2009. Nutrient uptake and yield of hybrid maize (Zea mays L.) and soil nutrient status as influenced by plant density and fertilizer levels. Int. J. Agric. Sci. 5: 193-196.

Thakur, D.R., O. Prakash, P.C. Kharwara and S.K. Bhalla.1998. Effect of nitrogen and plant spacing on yield, nitrogen uptake and economics in baby corn (Zea mays). Indian J. Agron. 43(4): 668-671.

Wu, S.C., Z.H. Cao, Z.G. Li, K.C. Cheung and M.H. Wong, 2005. Effects of biofertilizer containing $\mathrm{N}$-fixer, $\mathrm{P}$ and $\mathrm{K}$ solubilizers and AM fungi on maize growth: a greenhouse trial. Geoderma 125: $155-166$.

\section{How to cite this article:}

Zothanmawii, Edwin Luikham and Mariam Anal, P.S. 2018. Growth and Yield of Hybrid Maize as Influence by Levels of Nitrogen and Biofertilizer. Int.J.Curr.Microbiol.App.Sci. 7(08): 1864-1873. doi: https://doi.org/10.20546/ijcmas.2018.708.214 